\title{
THE POLKA VERSUS THE WALTZ \\ CZECH NATIONAL DANCES IN THE POLITICAL CONTEXT OF \\ THE NINETEENTH CENTURY
}

\section{DANIELA STAVĚLOVÁ}

The polka and sousedská become such familiar concepts of Czech culture that they have been generally accepted as folk dances and national dances - that is, Czech dances. When searching for the form of these dances in classic Czech collections of folk songs and dances, one is confronted by a very varied and contradictory picture, one that does not allow unambiguous characterization. This research is mostly interested in what helped these dances gain the status of $C$ zech folk dances and national dances, and how they worked as symbols of Czech citizenship.

Keywords: dance, polka, waltz, ethnicity, national identity, Czech Republic
Polka in sousedská sta postala tako znana koncepta v češki kulturi, da sta splošno sprejeta kot ljudska in nacionalna, tj. čška plesa. Pri iskanju in pregledu oblik teh plesov v klasičnih čeških zbirkah ljudskih pesmi in plesov opazimo zelo raznovrstno in protislovno podobo, ki onemogoca nedvoumno opredelitev. Raziskava je bila usmerjena v iskanje odgovora na vprašanji, kaj je bilo odločilno, da sta plesa pridobila status češkega ljudskega kot tudi nacionalnega plesa in kako delujeta kot simbol češke nacionalnosti.

Ključne besede: ples, polka, valček, etnična pripadnost, nacionalna identiteta, Čška

The polka and sousedská have become such familiar concepts of Czech culture that they have generally been accepted as folk dances and national dances_- that is, Czech dances. This is evident from the fact that several major Czech composers included them in their series of Czech dances: Bedřich Smetana, Antonín Dvořák, and Bohuslav Martinů. Yet, is this really so? When searching for the form of these dances in classic Czech collections of folk songs and dances, one is confronted by a very varied and contradictory picture, one that does not allow unambiguous characterization. This diversity of movement and music gives rise to numerous questions about the cultural origin of these dances, the circumstances of their origin, and their future existence. However, this study does not seek to explore the history of their origin. Many of the circumstances relating to the origin of the polka have been explained in separate studies (Nejedlý 1951; Stavělová 2006); the sousedská (literally, 'the neighbor's dance'), for its part, is known to have first appeared at the first Czech ball, held on Slavic Island (Slovansky ostrov, formerly Barvirský ostrov 'Dyer's Island') in the center of Prague in 1840. Because no reference was made to these dances in the 1819 government-initiated collection (Stavělová 1996), they can be safely called products of the nineteenth century.

The nineteenth century saw a growing awareness of Czech national consciousness, enhanced significantly, starting in the early 1820s, by the social and economic growth of townspeople coupled with the strength of the idea of nationalism. Czech national consciousness stood at the core of townspeople's cultural life, with social and cultural events 
serving as the driving force behind the national and democratic ideologies. Historiography has pointed to the importance of several national revivalists; on the other hand, it must be emphasized that these very personalities were well aware that it was the rich activities of cultural societies in towns that gave momentum to the idea of nationalism (Seibt 1996: 192-194).

The influence of Herder meant that one of the characteristic developments of the Czech national movement was the nation's growing historical awareness of its own values; in fact, Czechs would continue to refer to these values until well into the twentieth century. This awareness was based on Herder's categories of Germans and Slavs, with Germanic conquerors placed in contrast to the subjugated Slavs, and militant aristocrats in contrast to humane democracy. Attempts at defining the nation's identity as distinct from that of Germans grew stronger particularly after the 1848 Revolution, which brought into the Czech Lands a sense of national awakening and growing national disintegration (Seibt 1996: 182-192). It was thanks to cultural societies that the national consciousness gradually expanded to the remotest areas of the country, especially in the 1860s, which saw growing democratization and politicization of the masses (Connor 2003; Dann 2003; Hobsbawm 2003; Hroch 2003).

Therefore, it is advisable to seek references to "national dances" in Czech patriotic circles. Zdeněk Nejedlý (1951), writing about Smetana in a chapter called "Tanec" (Dance), mentions standardization of folk dances (i.e., establishment of a standardized form of the dance, consisting of a single motif) among patriotic townspeople, who, for obvious reasons, were ready to appropriate anything from the previous dance experience that best suited their taste and fulfilled the demands of the period. Patriots thus became a specific community with their own communication space, where dance assumed the role of one of the most crucial tools of symbolic language (Cohen 1974).

\section{A MYTH OR AN INVENTED TRADITION?}

It is interesting to explore the way that dance gained its prominent symbolic position in this environment and what enabled individual dances to assume the status of Czech national dances. What is certain is that at one point they became visible signs of the nascent Czech society; however, their cultural origin has remained unclear. They can therefore be considered modern myths because the term myth clouds or suppresses facts that remain invisible. According to Barthes (2004: 107), a myth reflects false evidence and serves as something of a language. What places these dances into the domain of myths is the contradiction between the signified, which is the genuine music and dance structure and multicultural origin of the dances, and the signifier - that is, their names. The signifier is distant from the signified reality, the distance being caused by the role assigned to the dance: it is supposed to be something that is represented in the mind of the nation, creating an image of the 
Czech national character. These stereotypes have survived to this day, with the sousedská understood as a symbol of calm, judicious yet merry demeanor. In contrast, the joyous or even hot-tempered polka symbolizes joyful optimism and awakening.

To understand the real meaning behind the names of these dances, it is necessary to carry out a thorough exploration of the circumstances of their origins and future existence. The discursive nature of their existence mostly originates in the fact that a certain group of people appropriates these concepts in order to manipulate them in space and time, infusing them with meaning that was not assigned to them by the previous socio-cultural environment, and making them remote from the previous reality of historical development. The driving force behind this process was the nineteenth-century Czech patriotic society, in which the dances in question became important signs of shared ideas and contributed to the creation of an image of the Czech nation's identity. The patriots made every effort, as Macura (1998: 55-62) notes in Česky sen (The Czech Dream), to invent identity in a way that was in line with the national revival movement. They did realize, however, that identity is a "fact of culture" and only becomes effective when this fact of culture is woven into the network of other facts of culture, past and present (ibid.).

The object of this discussion could also be considered an "invented tradition," as characterized by Hobsbawm (1983). What is much more important, however, is how one understands the terms nation and nationalism. Whether it is the primordialist conception of the nation as an ancient category or the radical constructivism of the 1990s (Gellner 1993; Hobsbawm 1983), which speaks of an arbitrary "invention" of a nation, one thing is certain: the abstract community was shaped under the influence of objective external factors. Therefore, of primary interest are the forms and methods of promoting the nationalist cause; attention is devoted below to national symbols, festivities, and stereotypes.

The creation of national identity can be understood as a process of growing collective political consciousness, with members of a community finding that they share traditions and interests that they then use as points of departure for common political aims (Smith 2003: 270-293; Eriksen 2007). The term often associated with the construction of national consciousness is awakening. This metaphor, Gellner (2003: 403) suggests, explains a situation in which people need to be awoken to realize their national identity and the political imperatives contained in it; that is, to be awoken to the need to protect national culture by providing it with its own protecting state as well as being awoken to the need to identify, neutralize, and expel foreigners determined to pollute and eliminate this culture. This is evidence that the nation has existed-but that it has only been asleep.

Exploring the environment of a dance thus becomes a specific form of studying the process of the creation of national identity, employing cultural knowledge in a unique way. Cultural knowledge — or, in my case, dance knowledge-is a phenomenon whose existence requires specific conditions and the knowledge of a dance code. In other words, the dance skills demanded and sanctioned by a society cannot be acquired overnight; equally slow are changes in the dance repertory that occur within society as a whole, and are therefore not 


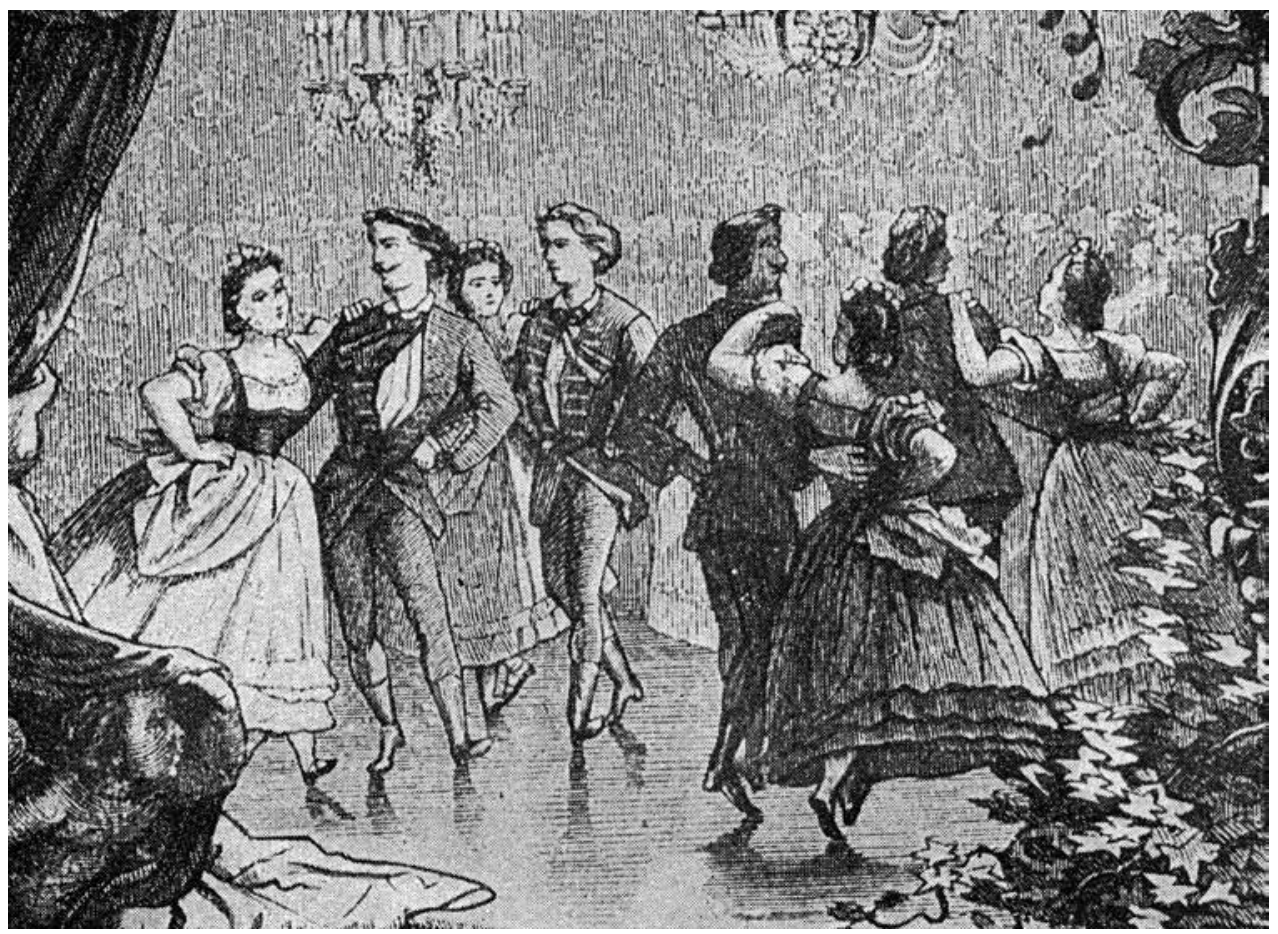

A dance (probably the polka) on the front page of the 1863 edition of Česká Beseda.

initiated by individuals. Normally, any dance considered new is in fact a modified dance experience that has existed in society under a different name, rather than a sudden impulse of an individual person. What is much more important is to explore the circumstances of such changes - and it is these circumstances that supply the key to understanding the symbolic language of dance.

One of the vital clues for understanding the symbolic value of several dances is the beseda, a Czech ballroom dance that originated in 1863 and is composed of folk dances from Czech rural areas; the dances contained in this popular suite are those that are best suited to the demands for the promotion of the nation. ${ }^{1}$ The dance, a ball-room quadrille, became an important vehicle for the Czech cause for several decades; the selection of dances representative of the Czech countryside helped promote the process of creating ethnic consciousness.

1 The beseda is a suite of dance movements from ten folk dances, whose steps and figures were combined to form something of a ballroom quadrille. Initiated by the poet Jan Neruda—and performed by him first at the Konvikt Inn in Prague on November 13th, 1862, the beseda was co-created by the dance teacher Karel Link (1823-1911) and the composer Ferdinand Heller (1824-1912). The first printed version of the dance was published in French in 1863, followed by numerous Czech editions that saw various changes and revisions (e.g., the original instrumental accompaniment was later expanded with song lyrics, overtures, and intermezzos). The name of the suite itself changed as well, from "the Czech ballroom dance beseda" to "the Czech beseda." 


\section{"CZECHNESS IN ALL ART"}

Czech character in all art was a well-known motto of the cultural politics of Jan Neruda, a national liberal, poet, and writer (1889). In his reflections on art, Neruda (1950) emphasized several features and signs that national art should represent; he thought the same features were to be promoted in cultural and social life, where he found there was little genuine enthusiasm for the Czech cause. In one of his feuilletons from the late 1880s, he appreciated the "electrifying" effect of music; similarly, and much earlier, he had realized the potential of dance, especially as a source of self-exploration, energy, and awakening:

Dance rhythm has precisely this effect. It is a mirror wherein we can see our own appearance, spontaneously and far from all self-complacency; we can feel ourselves in the sounds of dance and identify with them; we become fiery, wildly fast, and as dignified and tenderly joyous as the sounds. We sacrifice our personalities and enjoy the sound and movement which possess our whole beings. Without music, dance would be nothing like this ideal feeling, and we would have none of these diverse moods. (Neruda 1923: 199)

In his extensive 1869 study entitled $O$ tanci (On Dance), Neruda (1923) refers to the significance of dance in different historical periods, citing numerous examples of how different cultures employed dance in their social life, realizing that there is more to dance than just entertainment or ceremony; dance can become a means of education or communication. The study opens with a quotation by Rudolf Voss, a dance teacher from Berlin, who is reported to have said: "the worse public life is in a country, the worse-that is, the more stupid and desolate—is the way that country's people dance" (Voss 1869). Neruda continued:

It can safely be said that just as a public dance ball is an indicator of the country's political situation; the way an individual person dances says a great deal about his or her nature and education, whether he or she is temperamental or lazy, conformist, or radical in his or her political views. (Neruda 1923: 191-192)

A parallel is then made between the style of dance and the flabbiness and lack of enthusiasm characteristic of domestic political life in the 1860s:

And what about our dance? When a quadrille or beseda is danced, there is mere walking, not dancing; the polka and kvapík [gallop] are shuffled rather than danced, and dancers move according to the tempo yet 
with little enthusiasm; indeed, there are hardly any good dancers, only fast ones who have powerful lungs or do not mind their tuberculosis. (Neruda 1923: 192)

These reflections show how well aware Neruda was of the power of dance. His study, therefore, was intended to contribute to the promotion of the Czech nation, with dance, Neruda notes, being a powerful instrument of such promotion. In highlighting its positive values, its significance, and its potential, the author sought to explain the natural role that dance had played in the nation's life for a very long time (Neruda 1923: 207). At the same time, he points out that, although dance is deep-rooted in human nature, people need to learn dance skills in order to make dance a powerful tool of communication. Neruda is therefore disappointed by the lack of enthusiasm about learning dance knowledge and draws a parallel with the nation's weariness and sleepiness, features that he often mentions when referring to the lack of involvement in politics:

It is, unfortunately, fairly typical of our time that [dance] art is called a "stupidity"; much more stupid things are done, even by artists; our dancers are unwilling to acquire excellence in dance, being nothing but marquer la danse. I do realize that our political, public life is tough and each instance of joy shown in public looks unaesthetic, like face make-up. And I know that things cannot turn in the opposite direction all of a sudden. Yet I would be grateful if our sense of beauty does not collapse. (Neruda 1923: 195)

For Neruda, dance skills are associated with positive values that can make a convenient contribution to the nation's characteristics. He therefore places an emphasis on aesthetic values that help shape the picture of characteristics showing the nation in a favorable light. Another distinctive feature of dance, says Neruda, is that it stems from "human nature," its quality thus reflecting its originality. According to Neruda, the reason why these visible features were absent from Czech society was the flabbiness of political life that was unable to contribute to the creation of national consciousness (ibid.). A parallel is then drawn between this condition and the situation on the dance floor, which-according to Neruda — was lacking in emotional experience:

People no longer dance out of joy, they now dance out of habit handed down from their fathers, and very often people dance out of speculation /.../ Dancing with an expression brings joy to the dancer as well as the audience. This, however, is a skill that needs to be acquired just like any other skill; a dancer needs more than a pair of red shoes. (Neruda 1923: 194) 
These reflections were in accordance with the policy of creating a national culture and were to serve, among other things, as evidence of the nation's dance culture, potentially a visible sign of its emancipation. Neruda was thus more than willing to publish studies on dance that were to testify to the significance and diversity of Czech dance culture. In 1858, a reflection entitled "České národní tance" (Czech National Dances) appeared in the first issue of the magazine Obrazy života, followed in 1869 by the study "O tanci" (On Dance; Neruda 1923, 1946), inspiring Alfred Waldau, who allegedly attended the dance classes taught by Link with Neruda, to write the first cultural studies exploring the history of Czech national dances $(1859,1860,1961){ }^{2}$

\section{THE CULT OF DANCE}

Neruda's critical comments on national identity are well known; the reason why he said the Czech nation was "dreaming," "asleep," or "buried alive" rather than "awake" was the bitter skepticism he liked to present in his writing (Macura 1998: 44), the parallel between empty patriotic rhetoric, and lack of enthusiasm for dance being a favorite metaphor that he used when referring to political life. His complaints were especially related to the period starting in the late 1860s, which saw a decline in public political life after the adoption of the Austro-Hungarian compromise and introduction of the concept of the monarchy as a parliamentary state and other democratic regulations.

It needs to be emphasized, however, that the early 1830s brought more favorable conditions for a different attitude to and reception of dance to how it had been understood and received by the elites in the previous periods; if conditions had been less favorable, dance could not have played its significant part in the process of promoting the national cause. As early as the first half of the nineteenth century, dance had become a manifestation of new life; the ecstatic words uttered — if with a degree of exaggeration-by Rubeš in the mid-1840s (Rubeš 1846: 319) "Ball! Oh, the sweet word ball!" reflect the social status of dance as more than just entertainment; indeed, people saw in it a deeper, more spiritual sense (Nejedlý 1951: 238). Dance was clearly becoming a distinctive language of the nascent class of townspeople, primarily reflecting their determination and an influx of new energy (Tyl 1844, 1926; Tomek 1904-1905).

2 Ottưv slovník naučný (Otto’s Encyclopedia) also lists Waldau under his birth name Josef Jarosch and mentions his German origin. A graduate of a law school, Jarosch adopted the pen name Alfred Waldau and worked as a journalist and author in Prague and Vienna until 1863, publishing several books, including studies on dance that introduced Czech culture to German readers. To this end, they were written in German (Gremlicová 2003: 46-47). The fact that Waldau's writings were biased, seeking to promote the ideology of the day, has been suggested by the German studies expert Georg Gimpl (in: Waldau 2003: 118-180) in his critical edition of Böhmische Nationaltänze (Czech National Dances). 

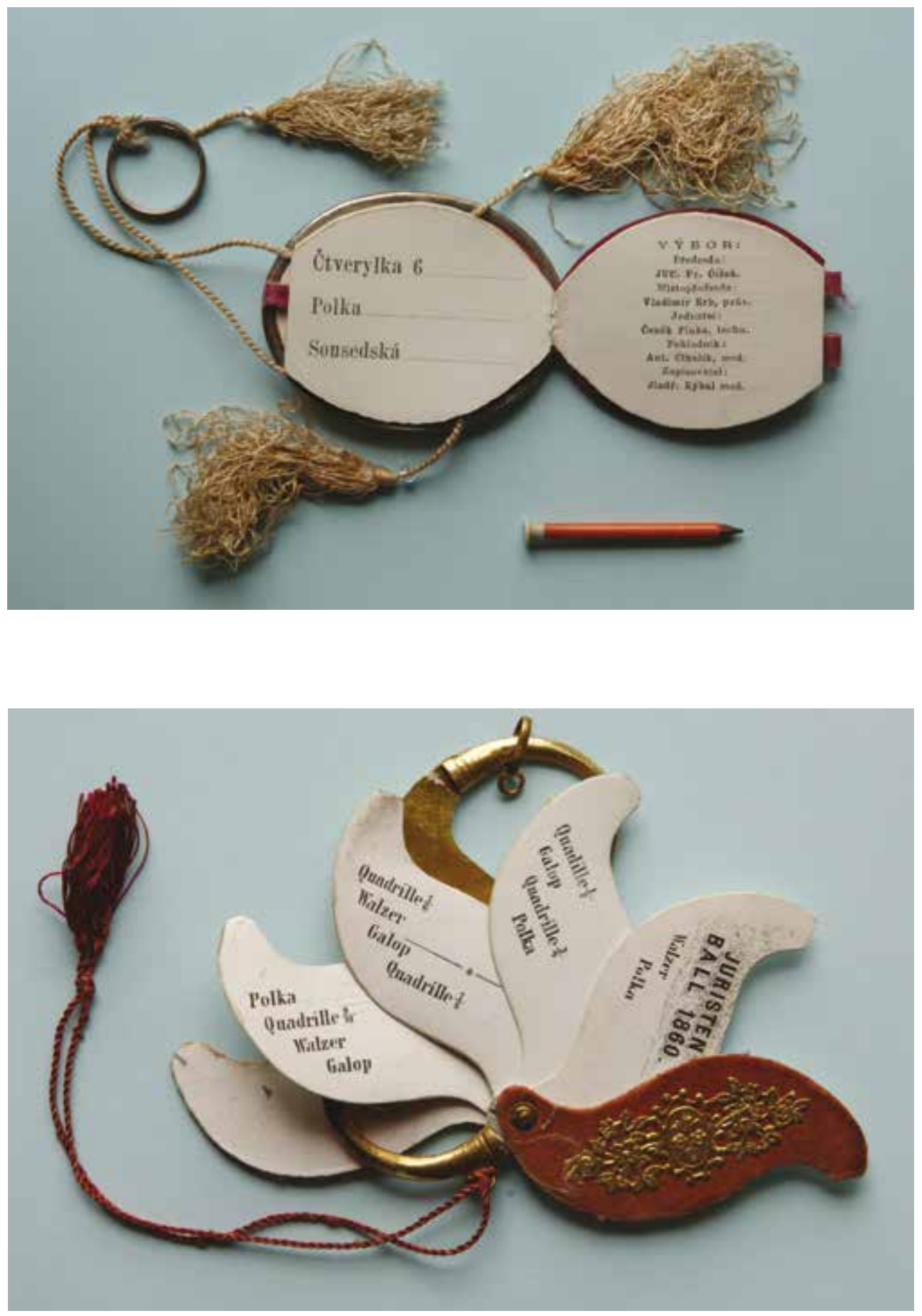


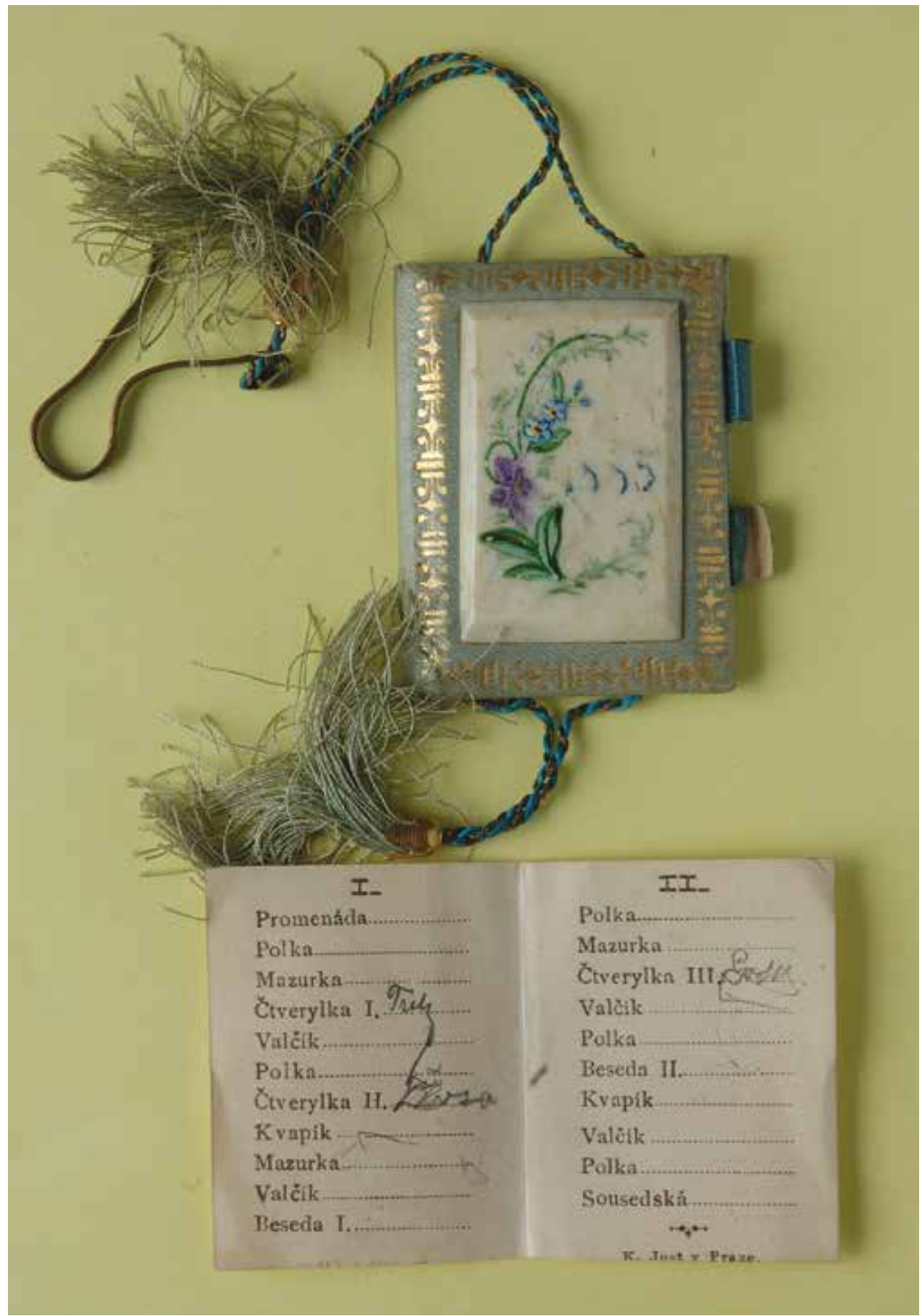

Prague ballroom dance orders from the second half of the nineteenth century, kept in the archive of the National Museum in Prague. 
Every form of entertainment pursued by a patriotic society had to be in harmony with a more superior idea of the day. The conviction that cheerfulness was the core feature of Czechs was the reason why dances were sought that would fulfill this idea; evidence was presented to prove that dance was second nature to Czechs and the importance of dance for the nation was discussed. This idea was promoted, among others, by Jan Jeník of Bratřice, a personality that enjoyed popularity in the patriotic circles; in his 1838 Bohemika, he wrote: "Czechs are born with a cheerful mind, and so they love singing and dancing more than anything" (Nejedlý 1951: 227-228).

The cult of dance was active even outside ballrooms, affecting the musical life of those times. No difference was seen between composers of dance music and those of concert music, and these two musical genres often overlapped in the works of classical composers. It was only natural that dance music was heard from concert halls, dance was often employed in operas, and entire concerts were devoted to dance music.

Czech patriots were increasingly aware that not only arts but also culture in a wider sense can become a tool for mobilizing numerous supporters that could help achieve political aims; dance seemed to have all the potential to become such a mass tool of political campaigning (Borovský 1845; Malý 1872; Míka 2008; Stavělová 1993). Dance came to be understood as a cultural sign, contributing to the nation's external characteristics; therefore, attention was increasingly focused on forms that fully met this demand. The country's social life, nevertheless, offered a very diverse spectrum of dance forms that were products of various European trends rather than being rooted in domestic tradition. Therefore, it was necessary to bring to life new products that would meet the demand for dances adequately representing the nation, which was gaining increasing emancipation. It was perfectly natural that this role of mediator was assumed by the beseda, which almost immediately became an important sign of national consciousness during dance events attended by all classes of the urban and rural population (Link 1891; Vycpálek 1963; Bonuš 1971). It was no coincidence that the personality that was the initiator and an avid campaigner for this was the patriot Jan Neruda, the first person to perform the dance when it first appeared at the Konvikt Inn in Prague in 1862.

\section{“NATIONAL DANCE” AS A TERM}

In a similar vein as the camara, the clothing worn by patriotic activists, national dance became a visible sign easily decipherable at first sight. It appears that the use of national dance as a term in association with dance events was deliberate; the least this term was supposed to do was to help distinguish dances of superior quality from "ordinary" dances. Moreover, national dances were thought to have a superior mission of representation rather than mere entertainment. The question is what effect this had on the movement's structure. They were expected to be representatives of long-term tradition and rural culture because such were 
the demands for the search for national values. Another important aspect, however, was the dance experience and conventions, which only permitted the import of cultural products that the nation was able to identify with. The creation of the beseda in 1863 was undoubtedly a lucky affair. The quadrille and contredanse were a popular group dance formation among European townspeople, enjoying their renaissance under the standardized French name quadrille. In the early 1840 s, the popularity of these dance formations arrived directly from the center of new fashion, Paris; even the polka, until then performed by individual couples, was given a new form in the "polket en colonne" (Zíbrt 1960: 325; Stavělová 2006: 17). Another asset of the Czech ballroom dance is that the beseda consists of ten dances of folk origin that could be regarded as national. Most of these were performed separately, since the 1830s, at town balls and were increasingly understood as genuinely Czech dances. Thus names such as polka, sousedská, furiant, rejdovák and rejdovačka, obkročák, řezanka, dvojpolka, kalamajka, hulán, strašák, and kuželka had been in popular use for some time. ${ }^{3}$

It is hardly possible today to determine how, for instance, the polka was danced in 1838, when it hit dance rooms in Prague, and when it became increasingly emblematic. Nor is it possible to reconstruct the sousedská as it was danced at the first Czech ball in 1840, ${ }^{4}$ where its performance was undoubtedly in compliance with demands for Czech character in art. The other question remaining unanswered is how these dances were performed before becoming part of the beseda; therefore, it is open to speculation what transformation folk dances might have undergone to become eligible for the status of national dances. Little is provided by the 1819 government-initiated collection (Stavělová 1996), which contains no dance descriptions, making their initial form a subject of speculation. What undoubtedly influenced the form of these dances once they started to be performed as part of the national quadrille was the spatial arrangement and grouping of individual dance motifs into independent wholes called figures, which are subdivided into tours. The beseda is a combination of dance steps from different dances, randomly mixed to produce pleasant contrasts of fast and slow steps and, more importantly, to use the individual steps to make spatial changes and exchanges of dance couples, which are required by the form of the quadrille.

The crucial features of beseda dances are inherent in their very mission, explained in the foreword to the second edition of Beseda by the coauthor Karel Link:

3 Of the names above, only the following appear in the 1819 government-initiated collection: furiant, rejdovák, řezanka, and kalamajka (Stavělová 1996: 103-105).

4 February 5th, 1840 saw the first Czech public ball, sponsored by Josef Kajetán Tyl and his supporters. Unlike the previous domestic balls and other dance events, this was supposed to be a genuine manifestation of the Czech cause; Czech was mostly spoken, and Czech entrance tickets and programs were distributed. It was on these materials that the name sousedská first appeared; a great deal of sensation surrounded the menu, translated into Czech by Tyl himself and taken home by the guests as a souvenir (Nejedlý 1951: 250-254). 
Since these dances, combined into a pattern, have a unique characteristic and beautiful steps, it is inevitable that they be performed in a skilled and graceful manner; even when danced in ballrooms, their national nature should be visible. It is necessary to avoid excessive jumping and coarse stamping, and one should ensure that the dancing is equally appealing to the audience's eyes as well as ears. (Link 1891: 5)

The demand for aesthetic quality was the primary guideline for how the dances were performed and which features from their previous forms had been omitted or transformed.

Writing a postscript in the same edition of Beseda, Link calls for greater interest in the original form of "Czech national dances that the beseda is composed of," adding that "even when the figures of Czech national dances started to be used as part of the ballroom dance, they had retained much of their characteristics regarding their steps and figures" (Link 1891: 44-45). Link refers here to dance motifs only; the initial forms of individual dances had been abandoned. Indeed, the dance notation of Beseda opens with a description of the steps: sousedská, furiant, rejdovák, polka, dvojpolka, kalamajka, obkročák, hulán, and řezanka. This is followed by the composition of figures and tours. In this way, a new dance form is created using steps and figures of dances that Link calls national; what he most likely refers to is the form created by town ballrooms in the first half of the nineteenth century rather than any genuinely folk form because it is not clear where he obtained the facts he had about folk dances. Because he worked with dances mentioned in Neruda's Czech National Dances and in Waldau's cultural study, this involves a single source: the dance repertory of the patriotic population of small towns, who-starting in the early 1830 s-learned selected rural dances in order to manifest their openness to the ideas of liberalism. ${ }^{5}$

In any case, formal composition appears not to be the only factor determining the form of national dances in those days. What mattered, therefore, was not so much how a dance was performed but how it was received and perceived by society; no less symptomatic was who it was performed by and on what occasion. In other words, the mission attributed to a dance by society mattered more than its form.

Evidence is found, inter alia, in a reference to the rejdovák and rejdovačka by Jan Jeník of Bratřice: "Both had the same beautiful music, although the only difference was that the music played by the band was rather slow in the rejdovačka and temperamental in rejdovák, and so the music set the tempo for the dancers. The figures of these dances were very pleasant. After the lords from Prague returned home and their sons saw the two dances performed by their subjects in village pubs, they fell in love with the rejdovák, much more than with any other dance. Having learned the dance, they then taught it to their sisters. Consequently, no ball held by the nobility and respectable people could afford not to include the rejdovák" (Zíbrt 1960: 336). 


\section{THE POLKA AS AGITATOR}

The polka, regarded by Neruda (1946: 9) as the principal Czech dance, is the only dance in Beseda that appears in two forms: the first is the lively, marching tempo with the couple moving exclusively with an alternating step (alternating right and left foot at the opening of the motif); the other was a slower double polka, with a peculiar tip-and-heel motif (Stavělová 2006: 19). Neruda considered the polka an important tool for promoting the national cause. As mentioned above, dance was more than entertainment for Neruda, who was aware of the potential that dance holds for social communication. He was inspired by the symbolic language of the dance when writing his poem "Balada o Polce" (The Polka Ballad). Polka, a vigorous and healthy village girl, arrives in Prague, the center of all patriotism, to rouse to action all those "asleep." In the mid-1880s, Neruda called for the return of polkamania in his feuilleton "O taneční hudbě" (On Dance Music) in the daily Národní listy, venting his annoyance over the lack of nationalist awareness (Neruda 1923: 158). $\mathrm{He}$ believed that the nation could be roused to action only by the kind of enthusiasm that the polka caused when it first arrived.

From the late 1830s onwards, the polka performed its social role perfectly well; there was hardly anyone that would not dance the polka, the dance becoming something of an entrance ticket into the patriotic circles (Nejedlý 1951: 348; Stavělová 2006: 8-11). Its national values were indicated less by its form and style of performance than by discussions over its Czech origin, which filled the pages of the magazines Kvéty and Česká včela in the 1840s. Considered the major tools of nationalistic campaigning, these magazines turned out to be the most suitable vehicles for promoting the polka among the Czech people. The publication of the myth concerning the creation of the polka, later denied and substituted by new speculations, assisted in establishing its symbolic value, in which the folk nature of Czech rural areas played a crucial part (Nejedlý 1951: 334-345).

The polka, as depicted in collections of the late nineteenth century, was a mixture of cultural elements that had been domesticated in the Czech countryside in the first half of the nineteenth century but were of Russian, Hungarian, or other origin (as evident from the name of the dance or from notes made by the informants).

This, apparently, bothered no one; the multicultural dance motifs and diverse performance styles did not prevent the dance from being perceived, at one point, as an unambiguous national symbol. That point came when it was apparent that the dance was able to meet certain expectations. The polka was the first dance that—as a round dance-could compete with the German waltz, become enormously fashionable and still make everyone believe it was different from German dances; thus it had the potential of becoming the long-awaited domestic dance. However, the polka only became a national symbol long after it swept the local ballrooms, its lively rhythm complying with the attitudes and determination of the nascent class of townspeople of all nationalities. For Neruda, the existence of the polka was an answer to the call for a vigorous and victorious influx of nationalistic awareness, 
which was supposed to accelerate the creation of ethnic identity. Neruda appreciated the polka's ability to rouse people to action: according to Neruda, polkamania could make the nation enthusiastic about a shared cause. More than anyone else, he realized the enormous potential that the polka, so popular both in towns and in the country, had as a vehicle for promoting ideas. When the suite Beseda was being composed, the polka was the numberone candidate, simplified to the maximum extent to be easily accessible by all those ready to carry its banner.

\section{WOULD YOU CARE TO DANCE A WALTZ, HOUPAVÁ, OR SOUSEDSKÁ?}

The popularity of the waltz, dominating Czech dance culture since the early 1820 s, went against the grain of some patriots. It was Josef Kajetán Tyl in particular that felt he had to somehow come to terms with this dance; being the first to look for a more adequate name for the dance that would have been difficult to evict from dance events, Tyl came up with a suggestion in 1833 to rename the German-sounding waltz the houpavá (the 'sway dance'). In his essay "Pannám českým ponížené mé služby" (My Humble Service Offered to Czech Maidens), published in the magazine Jindy a nyni, Tyl wrote: "Pardon me, my patriotic maidens, if my words were less appealing to you than Strauss's last houpavá (waltz) during the wedding held recently" (Nejedlý 1951: 291). The term houpavá, however, remained restricted to Tyl's writings and, even though he continued to persistently refer to a waltz as a houpavá, he later abandoned the term (ibid.).

Another, more successful attempt was that of introducing the sousedská into public life. The judicious yet merry dance was to become a counterbalance to waltz and, at the same time, a more relaxed counterpart to the fiery polka. What was expected to appeal to the masses was less the movement structure-initially somewhat ambivalent-than the name itself, which complied with all the expectations. The sousedská, as mentioned above, first appeared in the first Czech ball, in 1840, the name being fully in accordance with the expectations of society.

The feminine gender of the name sousedská is, in a similar vein to the polka, no coincidence either. Women's involvement in national awareness-raising was one of the crucial items of patriotic policy with its own norms of love life, where the ideal connection is that of a Czech man and a Czech woman. Czech character had become one of the primary aspects of female beauty; in the eyes of patriotic society, the cult of naturalness and genuineness equaled linguistic and national naturalness and genuineness; another popular theme was the blending of romantic love and love of country, as canonized in Slávy dcera (The Daughter of Sláva) by Jan Kollár (Macura 1983: 148). Women’s participation also meant a considerable expansion of the social classes involved in the patriotic movement, helping this social group step out of its isolation and cross the boundaries of its microworld (ibid.). This was partially made possible by the stereotype of "fighting women," previously so popular in 
Europe, which in the mid-nineteenth century was made into a symbol of how the existing order is overturned during a revolution (Macura 1998: 81). This tendency was visible in numerous dance names, with dances assuming the status of national dances through a simple operation of changing the name to its feminine alternative. Thus, the vigorous skoćák became the lively skočná, the dupák was made more delicate under the feminine names of dupavá and dupavka; and, in newly coined names such as polka and sousedská, the feminine form was the only imaginable choice, with the aim of satisfying the expectations of the day.

Nevertheless, the sousedská remained absent from subsequent balls, only to reappear in the 1860 s as part of the ballroom quadrille, the beseda. Later, it would regularly appear in town dance events as an independent dance and also became a staple of village dance events. Classic collections of folk dances provide evidence that the steps of the sousedská were adopted into dances with variable rhythms as a reliable substitute for the steirisch $\left(s_{t a j r y s)}\right.$. The sousedská was often performed as something of a folk waltz by repeating a single motif. The variations in the notations only concern the accompanying song that determined the tempo and style. Instances with more dance motifs yield themselves to comparison with an older generation of dances performed in the Czech Lands under the names lendler (< Germ. Ländler), tajč (< Germ. Deutsch), and štajryš (< Germ. Steirisch).

A similarity with the ländler is found particularly in the sousedská križzek (križzek meaning 'cross' in reference to the couple dancing across the room in a cross fashion, quadrille-like), a dance recorded in the Chrudim and Nasavrky regions; in both these dances, the couple turns under their joined arms. Josef Zemánek (1912: 416), the collector that recorded dances in these regions from 1903 to 1920, notes that the sousedská is a dance whose performance followed no fixed rules, and goes on to list several possibilities, including the lady's solo rotating on the spot, her moving backwards in a rotating fashion from the man, and the couple's turning under their raided joined arms; in addition, the dance was often performed in rows. In the sousedská in the proper sense, according to Zemánek, the couple would keep turning towards and away from each other:

The boy would take the left hand of the girl standing to his right, with his right hand. In the opening bar, they would put their joined arms back and turn to face each other; in bar two, they would stretch their arms forward and turn away from each other; they would repeat this many times during the whole dance or they would prepare for a round dance with which they would conclude the sousedská. (Zemánek 1912: 416)

It is interesting to note that Zemánek's description of the sousedská proper corresponds to how the dance is performed in Beseda. On the one hand, Karel Link, writing in his postscript to the second edition of Beseda, mentions the original version of the dance: 
The sousedská is enormously similar to the Austrian and Styrian ländler; however, the sousedská is a little more lengthy—indeed, it is often danced on one and the same spot. Another feature shared with the ländler is the intertwining of arms, left to the dancers' creativity. However monotonous the sousedská might appear, it is far from insignificant: the couple is presented as sharing longing and tender joy and dancing with light feet. It is a very popular dance at Sunday village music events, attracting the elderly as well. The songs that go with the dance often display merry jocularity, although others are sorrowfully elegiac. (Link 1891:49)

The sousedská step included in the ballroom dance the beseda is performed either as one motif (in the manner of a folk waltz) employed in most figures to allow shifts across the floor, or in an independent tour, with the sousedská described as follows:

the lady makes a move to the right with her right foot, the gentleman to the left with his left foot; turning several times away from each other and towards each other, they make four steps of the sousedská, upon which each gentleman takes his lady for a dance, making a round for four bars of the sousedská, in a circular fashion, leftwards to the opposite place. (Link 1891: 15-16).

No less interesting is the description of the sousedská in Národopisný sbornik okresu Horického (Ethnographic Anthology of the Hořice District), noting the close similarity of the sousedská and the waltz. The collector J. Hynek, whose collection closes with a reference to Link's beseda, which he drew upon, notes that

the sousedská, which is being replaced by the waltz—and the two are sometimes mistaken for one another-has a slower tempo and, indeed, is often danced on one spot. Either it is danced in a round or with the dancers rotating under their arms, or as cross-step waltz: the boy lets go of the girl, who then rotates away from the boy and is followed by him; alternatively, the boy rotates away from the girl and is followed by her. (Národopisný sborník 1895: 416)

The contamination of the sousedská and waltz is also found in a number of other collections of the late nineteenth and early twentieth centuries; the sousedská is something of a folk waltz with steps made with a degree of springing in the knees. Zemánek (1912: 504) mentions a "shuffling" and "swaying" waltz and he applies the term "shuffling sousedská" to refer to the soupák (shuffle dance; ibid.: 500). These collections often refer to the same 
type of dance motif alternately as the sousedská and waltz, with the waltz mostly denoting steps in a more lively tempo.

Both the descriptions from the Chrudim and Hořice regions contain features that were obviously derived from the older ländler; however, they consistently refer to the style of dance as the sousedská. Clearly, the tradition of older German couple dances intermingled here with a newer fashion of the ballroom quadrille, with especially the couple's turning away from and to each other (preferred in Beseda) being highlighted as a core feature of the sousedská.

In other words, the sousedská appeared in the early 1840 s as a brand new dance, but this name, complying with the expectations of the day, conceals traditional dance knowledge that was established in the Czech Lands under the influence of older German couple dances. Reliable clues can be obtained from the government-initiated collection of 1819, which does not list a single dance under the name sousedská in the country, though it contains a large number of ländlers. The standardization of the sousedská marks the end of the process whereby dance became the sign of social attitudes or behavior, representing specific national features. In those days, the sousedská was thought to be a neighborly, more sedate dance, as opposed to merry dances preferred by the young (Nejedlý 1951: 324). This gave the sousedská an exclusive position at the end of a dance event, where it was supposed to "move people's souls" and provide a dignified conclusion to the event. ${ }^{6}$

\section{BY WAY OF CONCLUSION}

The above facts suggest that it was, first of all, the names of dances that clearly indicated the Czech nature or Czech origin of dances, thus significantly contributing to the characteristics of the group that performed them. That was much more important than the form of the dance. This enabled movements or cultural stereotypes previously associated with a different nation or social class to live on under a new, more suitable name. The umbrella names polka and sousedská conceal a long-term experience of traditional dance culture that absorbed anything it was confronted with, including elements of different ethnic origin. It is, therefore, advisable not to explore these dances for genuinely Czech features, which is what several composers did whose intention was to contribute with their works to the picture of national culture; instead, attention should be paid to the reasons why certain dances could become national symbols - and also to why it was that dance, which had not enjoyed a good reputation in the previous centuries, that suddenly met with positive reception from society.

6 This is evidenced, inter alia, by a reference in the magazine Kverty, published after the first Czech ball in 1840: "The evening reached its merriest point in the small hours, when the sousedská with national tunes was played. How well-known these tunes are and how they move one's heart!" (Nejedlý 1951: 324). Similarly, Rubeš, writing in his Venkovanka, notes: "Everyone has had a great deal of dancing when, finally, the sousedská brings the merry evening to a close" (ibid.). 
This was evidently no coincidence; rather, society realized that the values contained in dance could be used as a tool for manipulation. First of all, however, people must have direct experience with this tool in order to learn about its effectiveness and how this experience could be applied in social communication. Jan Neruda was among those that explored the potential of dance, which, he found, could be used as an effective weapon; he employed all thinkable means that had the potential of appealing to the society of his day to awaken and rouse to action his nation and support the creation of national identity. Neruda knew that, in a society where dance had been the target of unprecedented attention since the first half of the nineteenth century, it had a massive potential for manifesting the growing importance of townspeople; he decided to exploit that potential. The cult of dance assisted him in meeting the requirement of mass dissemination of the Czech cause, which gradually came to be personified by some of the dances.

In addition to Neruda, other patriots realized the significance of dance culture, participating actively in its creation and understanding dance not as mere entertainment but, first of all, as a cultural sign. From then on, dance was understood as an entity that only exists in space and time, its semantic content continually renewing itself. Furthermore, the existence of dance, conditioned by mutual interactions, makes it a phenomenon that can only be perceived within the context of the social group in question. The introduction of selected dances as national symbols into the social scene was made possible mainly by the conscious acceptance of this function. Just as the most important thing in the creation of the patriotic circles was the supporter's acceptance of the Czech cause rather than his origin, it was the conscious recognition of selected forms of the diverse dance culture practiced in the Czech Lands - through the attribution of a suitable name - that turned these dances into national symbols. Some dances were able to play this role through all thinkable means; what was most important of all, however, was that, whatever their movement content was, it was a form sanctioned by society.

\section{REFERENCES}

Barthes, Roland. 2004 (1957). Mytologie [Mythologies]. Prague: Dokořán.

Bonuš, František. 1971. Českýs salonnitanec Beseda, jeho historie a tvưrci [The Czech Ballroom Dance Beseda: Its History and Creators]. Prague: Ústřední dům lidové umělecké tvořivosti.

Borovský, Karel Havlíček. 1845. Poslední Čech [The Last Czech]. Česká včela 52 (12): 211-212.

Cohen, Abner. 1974. Two-Dimensional Man: An Essay on the Anthropology of Power and Symbolism in Complex Society. Berkeley: University of California Press.

Connor, Walker. 2003. Národ je národ, národ je stát, národ je etnická skupina, národ je ... [A Nation Is a Nation, a Nation Is a State, a Nation Is an Ethnic Group, a Nation Is a ... . In: Hroch (ed.), 154-173.

Dann, Otto. 2003. Utváření národa v novověké Evropě [The Creation of a Nation in Europe in the Modern Period]. In: Hroch (ed.), 349-360. 
Eriksen, Thomas Hylland. 2007. Antropologiemultikulturnich společnosti: Rozumèt identitě [Anthropology of Multicultural Societies: Understanding Identity]. Prague: Triton.

Gellner, Arnošt. 1993 (1983). Národy a nacionalismus [Nations and Nationalism]. Prague: Josef Hř́bal.

Gellner, Ernest. 2003. Nacionalismus [Nationalism]. In: Hroch (ed.), 403-417.

Gremlicová, Dorota. 2003. Alfred Waldau: K dějinám českých dějin tance [Alfred Waldau. On the Czech History of Dances]. In: Historickéstudium tance veceském prostred: Sbornik praciz konference katedry tance HAMU konanéu príležitosti životního jubilea prof. Boženy Brodské, Praha 4. 11. 2002 [Historical Study of Dance in the Czech Lands: Proceedings from a Conference Held by the Department of Dance at the Music and Dance Faculty of the Academy of Performing Arts to Mark Professor Božena Brodskás Anniversary, Prague, November 4th, 2002]. Prague: Akademie múzických umění, 46-54.

Hobsbawm, Eric. 2003. Několik úvah o nacionalismu [Several Reflections on Nationalism]. In: Hroch (ed.), 109-124.

Hobsbawm, Eric and Terence Ranger (eds.). 1983. The Invention of Tradition. Cambridge: Cambridge University Press.

Hroch, Miroslav (ed.). 2003. Pohledy na národ a nacionalismus: Čitanka textů [Perspectives on Nation and Nationalism: An Anthology]. Prague: Sociologické nakladatelství.

Link, Karel. 1891. Beseda, český salonni tanec [Beseda, the Czech Ballroom Dance]. Compiled and written by Karel Link, a dance teacher. Second, completely revised edition. Prague: A. Storch syn.

Macura, Vladimír. 1983. Znameni zrodu: Českéobrozeníjako kulturni typ [The Sign of Genesis: The Czech National Revival as a Cultural Type]. Prague: Československý spisovatel.

Macura, Vladimír. 1998. Český sen [The Czech Dream]. Prague: Nakladatelství lidové noviny.

Malý, Jakub. 1872. Vzpominky a úvahy starého vlastence [Memories and Reflections of an Old Patriot]. Prague: Tiskem a nákladem J. S. Skrejšovského.

Míka, Zdeněk. 2008. Zábava a slavnosti staré Prahy od konce 18. do počátku 20. století. [Entertainment and Festivals in Prague from the Late Eighteenth to the Early Twentieth century]. Prague: Ostrov.

Národopisný sborník. 1895. Národopisný sbornik okresu hořickébo: 1895 [Ethnographic Anthology of the Hořice District: 1895]. Hořice: Nákladem redakčního komitétu národopisného odboru v Hořicích.

Nejedlý,Zdeněk. 1951. Bedřich Smetana IV: Nováspolečnost [Bedřich Smetana IV: A New Society]. Prague: Orbis.

Nejedlý,Zdeněk. 1954. Bedřich Smetana VII: Ve společnosti [Bedřich Smetana VII: In Society]. Prague: Orbis.

Němcová, Božena. 1929. Z Chodska a odjinud z Čech: Obrazy z okoli domažlického [From Chodsko and Other Bohemian Regions: Pictures from the Environs of Domažlice]. Prague: Kvasnička a Hampl.

Neruda, Jan. 1889. Českost ve všem umění [Czechness in All Arts]. Národní listy, January $20^{\text {th }}$.

Neruda, Jan. 1923. O tanci: Rozjímání dle velmi učených lidí [On Dance: Reflections with Very Learned Personalities]. In: Miloslav Novotný (ed.), Dilo Jana Nerudy VIII: Studie krátkéa kratší I. Uspořádal M. Novotný [The Works of Jan Neruda VIII: Short and Very Short Studies. Edited by M. Novotný]. Prague: Kvasnička a Hampl, 165-189.

Neruda, Jan. 1946. České národni tance [Czech National Dances]. Prague: Nová osvěta.

Neruda, Jan. 1950. O uméni: Kritická knihovna sv. 3 [On the Arts: Critical Library, vol. 3]. Prague: Československý spisovatel.

Rubeš, František Jaromír. 1846. Blahosti tanečnich hodin [The Pleasures of Dance Lessons]. (Sebranéspisy I [The Complete Works I]). Prague: I. L. Kober. 
Seibt, Ferdinand. 1996. Německo a Češi: Dějiny jednoho sousedství uprostřed Evropy [Germany and Czechs: The History of their Cohabitation in the Heart of Europe]. Prague: Academia.

Smith, Anthony D. 2003. Etnický základ národní identity [The Ethnic Foundation of National Identity]. In: Hroch (ed.), 270-296.

Stavělová, Daniela. 1993. Rukopisný materiál J. E. Konopase jako významný pramen pro studium lidového tance kolem poloviny 19. století [The Manuscripts of J. E. Konopas as a Significant Source for the Study of Folk Dance around the Mid-Nineteenth Century]. Českýlid 80 (4):321-334.

Stavělová, Daniela. 1996. Lidové tance v guberniálním sbèru z roku 1819 [Folk Dances in the GovernmentInitiated Collection of 1819]. Prague: NIPOS-Artama.

Stavělová, Daniela. 2006. Polka jako český národní symbol [Polka as a Czech National Symbol]. Český lid $93(1): 3-26$.

Tomek, Václav Vladivoj. 1904-1905. Pamétiz mého života [Czech National Dances]. Prague: W kommissi u Františka Řiwnáče.

Tyl, Josef Kajetán. 1844. Kusy mého srdce I [Pieces of My Heart I]. Prague: author.

Tyl, Josef Kajetán. 1926. Od nového roku do postu: Kus pražského života [From New Year’s Day to Lent: Several Months of Life in Prague]. Edited and annotated by Ferdinand Strejček. Prague: F. Topič.

Voss, Rudolf. 1869. Der Tanz und seine Geschichte: Eine kultur-historisch-geographische Studie [Dance and Its History: A Cultural-Historical-Geographical Study]. Berlin: Verlag von Oswald Seehagen.

Vycpálek, Vratislav. 1963. K historii české besedy [On the History of the Beseda]. Český lid 50: 180-184.

Waldau, Alfred. 1859, 1860. Böhmische Nationaltänze [Czech National Dances]. Prague: Hermann Dominicus.

Waldau, Alfred. 1861. Geschichte des böhmisches Nationaltänzes [History of Czech National Dance]. Prague: Kath. Gerzabek.

Waldau, Alfred. 2003. Böhmische Nationaltänze: Eine Kulturstudie. Seinem Freunde Johann Neruda gewidmet. Herausgegeben und kommentiert von Georg Gimpl [Czech National Dances: A Cultural Study Dedicated to My Friend Jan Neruda. Published and Annotated by Georg Gimpl]. Prague: Vitalis, Furth im Vald.

Zemánek, Josef. 1912. Tance našich okresů [The Dances of Our Districts]. In: Václav Hanus, Chrudimsko - Nasavrcko III [The Chrudim and Nasavrky regions III], Prague: Chrudim.

Zíbrt, Čeněk. 1960. Jak se kdy v Čechách tancovalo [The History of Dance in Bohemia]. Second edition. Prague: Státní nakladatelství krásné literatury, hudby a umění. 


\section{POLKA NASPROTI VALČKU. ČEŠKI NACIONALNI PLESI V POLITIČNEM KONTEKSTU 19. STOLETJA}

Zbrana dejstva kažejo, da so imena plesov sprva jasno izražala njihovo češko naravo ali češki izvir, s tem pa znatno prispevala k značilnosti skupine, ki jih je izvajala. To je bilo veliko pomembnejse kakor oblika plesa. Hkrati pa je omogočilo gibanja ali kulturne stereotipe, prej povezane z drugimi narodi ali družbenimi skupinami, da bi živeli v skladu z novim, primernejšim imenom. Glavni poimenovanji polka in sousedská skrivata dolgoletne izkušnje tradicionalne plesne kulture, ki je posrkala vse, sčimer se je srečevala, vključno z drugačnimi etničnimi elementi. Češki domoljubi so spoznali pomen plesne kulture, dejavno so sodelovali v njenem ustvarjanju in v razumevanju plesa ne le kot zabave, temveč predvsem kot simbola kulture. Tako kakor je bilo pri oblikovanju domoljubnih krogov najpomembnejše, da so njihovi podporniki prevzeli predvsem "češke razloge", tako je bilo za preoblikovanje teh plesov v narodne simbole - ob pripisu primernega imena - pomembno zavestno priznanje izbranih oblik iz pestre izvajalske plesne kulture v čeških deželah za nacionalne plese. Nekateri plesi so labko opravljali to vlogo na vse zamisljive načine; pri tem je bilo najpomembnejše, da je družba potrdila in sprejela plesno obliko, ne glede na njeno gibno vsebino. Jasno je, da to ni bilo naključje. Družba je spoznala, da labko vrednote, vsebovane v plesu, uporablja kot orodje za manipulacijo. Ljudje morajo najprej imeti neposredne izkušnje s tem orodjem, da se seznanijo z njegovo učinkovitostjo in načinom, kako bi te izkušnje labko uporabili $v$ družbeni komunikaciji. Jan Neruda je bil med tistimi, ki so raziskovali ta potencial plesa. Ugotovil je, da je v plesu moč, ki jo lahko uporabi kot učinkovito orožje. Na vse mogoče načine se je prizadeval, da bi z njim naslovil takratno družbo, da se prebudi in tudi prek plesa oblikuje nacionalno identiteto. Zavedal se je, da ima v družbi, kjer je bil ples vse od prve polovice 19. stoletja deležen izjemne pozornosti, ples ogromen potencial za manifestacijo vse večjega pomena meščanov. Zato se je odločil, da te možnosti izkoristi. Ples kot znak kulturnega mu je pomagal pri izpolnjevanju zahtev za množično razširjanje "čeških razlogov", ki so se postopoma utelesili $v$ nekaterih plesih.

Assist. Prof. Dr. Daniela Stavělová, Institute of Ethnology of the Academy of Sciences of the Czech Republic Na Florenci 3, 11000 Praha 1, Czech, stavelova@eu.cas.cz 